\title{
IMPLEMENTASI AMALIYAH YAUMIYYAH DALAM PEMBINAAN KARAKTER DISIPLIN SISWA: STUDI KASUS di SDIT AL-ZAHIRA KOTA SERANG
}

\author{
Nur Halimah $^{* 1}$, Firman Robiansyah ${ }^{* 2}$, Darmawan ${ }^{* 3}$ \\ UPI Kampus Serang, Serang \\ Email: nurhalimah@upi.edu*1, firmanrobiansyah@upi.edu*2 \\ darmawanwan@upi.edu ${ }^{* 3}$
}

\begin{abstract}
The role of character education is very important in building student discipline. However, there are still deviations from discipline which are a problem that must be addressed immediately. The following are some deviations from the student discipline character at SDIT Al-Zahira, namely: coming late to school, being late in collecting assignments, leaving class before break time, and taking dishonest exams. At SDIT Al-Zahira there is also a program that is a form of fostering student discipline character, namely the amaliyah yaumiyyah program. This program is in the form of habituation of daily worship such as prayer which aims to make students have a sense of self-awareness to the creator, discipline to worship, and to become individuals with strong faith and piety. From this habituation, there are several values of disciplinary character that are embedded in students, namely the value of cleanliness discipline, discipline in time, discipline in working on rules, leadership exercises, and togetherness exercises. The approach used is a qualitative approach with a case study method. The research subjects were students in grades 3 and 4 . The data were collected by means of interviews, documentation, and
\end{abstract}

\footnotetext{
${ }^{1}$ Fakultas Ilmu Pendidikan Universitas Pendidikan Indonesia Kampus Serang, Kampus Daerah UPI Serang Jl. Ciracas No.38, Serang, Kec. Serang, Kota Serang, Banten 42116

${ }^{2}$ Fakultas Ilmu Pendidikan Universitas Pendidikan Indonesia Kampus Serang, Kampus Daerah UPI Serang Jl. Ciracas No.38, Serang, Kec. Serang, Kota Serang, Banten 42116

${ }^{3}$ Fakultas Ilmu Pendidikan Universitas Pendidikan Indonesia Kampus Serang, Kampus Daerah UPI Serang Jl. Ciracas No.38, Serang, Kec. Serang, Kota Serang, Banten 42116
} 
questionnaires. The implications of the habituation of amaliyah yaumiyyah on the formation of students' disciplined character can be seen from the results of the questionnaire that has been filled out by 21 respondents. That $81.9 \%$ of students answered correctly and $18.1 \%$ of students answered incorrectly. This shows that there is an implication of the habituation of amaliyah yaumiyyah on the character building of students' discipline. From the results of these percentages, this amaliyah yaumiyyah habituation is highly recommended to be applied in schools as a form of disciplinary character building.

Keywords: Amaliyah yaumiyyah, Discipline, Character, Habituation.

\begin{abstract}
Abstrak
Peran pendidikan karakter sangat penting dalam membangun sikap disiplin siswa. Akan tetapi masih adanya penyimpangan terhadap kedisiplinan menjadi masalah yang harus segera diatasi. Berikut ini merupakan beberapa penyimpangan karakter disiplin siswa di SDIT Al-Zahira, yaitu: terlambat datang ke sekolah, terlambat mengumpulkan tugas, keluar kelas sebelum waktu istirahat, serta mengerjakan ujian tidak jujur. di SDIT Al-Zahira juga terdapat sebuah program yang menjadi salah satu bentuk pembinaan karakter disiplin siswa yaitu program amaliyah yaumiyyah. Program ini berupa pembiasaan ibadah sehari-hari seperti salat yang bertujuan agar siswa memiliki rasa kesadaran diri kepada sang pencipta, disiplin beribadah, serta agar menjadi pribadi yang kuat iman dan taqwannya. Dari pembiasaan ini ada beberapa nilai karakter disiplin yang tertanam pada diri siswa yaitu seperti nilai disiplin kebersihan, disiplin dalam waktu, disiplin dalam mengerjakan aturan, latihan kepemimpinan, dan latihan kebersamaan. Pendekatan yang digunakan yaitu pendekatan kualitatif dengan metode studi kasus. Subjek penelitiannya yaitu siswa kelas 3 dan 4. Adapun pengumpulan datanya dengan cara wawancara, dokumentasi, dan kuesioner. Adapaun implikasi pembiasaan amaliyah yaumiyyah terhadap pembentukan karakter disiplin siswa yaitu dapat dilihat dari hasil kuesioner yang telah diisi oleh 21 responden. Bahwa $81,9 \%$ siswa menjawab dengan tepat dan $18,1 \%$ siswa menjawab tidak tepat. Hal ini menunjukan bahwa adanya implikasi dari pembiasaan amaliyah yaumiyyah terhadap pembinaan karakter disiplin siswa. Dari hasil presentase tersebut pembiasaan amaliyah yaumiyyah ini sangat direkomendasikan untuk diterapkan disekolah sebagai salah satu bentuk pembinaan karakter disiplin
\end{abstract}


Kata Kunci: Amaliyah yaumiyyah, Disiplin, Karakter, Pembiasaan.

\section{Pendahuluan}

Lingkungan sekolah adalah lingkungan pendidikan kedua setelah keluarga. Sekolah merupakan lembaga yang dibangun pemerintah sebagai tempat untuk melakukan pendidikan. Sekolah merupakan sebuah lingkungan yang sengaja dirancang untuk melangsungkan proses pendidikan, sekolah juga dibuat berjenjang, berkesinambungan, dan memiliki aturan ${ }^{4}$. Sekolah disebut juga sebagai pendidikan formal karena terdapat proses belajar mengajar serta adanya tujuan yang harus dicapai di dalamnya.

Berdasarkan pemaparan tersebut dapat disimpulkan bahwa sekolah merupakan tempat untuk memperoleh pendidikan yang mana dalam operasionalnya ditunjang oleh peraturan untuk mencapai suatu tujuan yang diinginkan. Dalam hal ini tujuan sekolah yang dimaksud biasanya dikemas dalam bentuk Visi dan Misi yang dibuat serta disesuaikan dengan kebutuhan sekolah masing-masing.

Hurlock (dalam Senja) mengemukakan bahwa pemberlakuan aturan di sekolah ini salah satu tujuannya sebagai usaha pembentukan karakter siswa ${ }^{5}$. Fungsi dari aturan tersebut yaitu untuk membatasi perilaku yang kurang sesuai. Usaha dalam pembentukan karakter ini membutuhkan waktu yang tidak sebentar, akan tetapi membutuhkan proses yang cukup lama. Hal ini dikarenakan karakter merupakan sifat yang mendasar dari seseorang. Pendidikan karakter ini sangat penting diberlakukan dalam berbagai jenjang pendidikan yaitu dari jenjang Sekolah Dasar sampai dengan Perguruan Tinggi. karena menurut Azzet (dalam Maysaroh) dengan adanya pendidikan karakter sejak dini, diharapkan dapat mengatasi berbagai persoalan dalam dunia pendidikan 6 .

Hal ini sepadan juga dengan pendapat yang dikemukakan Kertajaya (dalam Majid \& Andayani) yang mendefinisikan karakter

\footnotetext{
${ }^{4}$ Sadulloh, Pedagogik (Ilmu Mendidik), (Bandung: Alfabeta, 2017)..

${ }^{5}$ Senja. Upaya Pembinaan Karakter Disiplin pada Anak Usia Sekolah Dasar Melalui Program Pembiasaan Salat Subuh Berjamaah. Skripsi. (Serang: Universitas Pendidikan Indonesia, 2015).

${ }^{6}$ Maysaroh. "Pembinaan Karakter Siswa Sekolah Dasar Melalui Program Pembiasaan Malam Bina Iman dan Takwa: Studi Kasus di Kelas IV SDIT Al-Hanif Tahun Ajaran 2018/201". Skripsi. (Serang: Universitas Pendidikan Indonesia Kampus Serang, 2019).
} 
sebagai salah satu sifat ciri khas suatu benda atau seseorang7. Yang mana menurut Sarkawi (dalam Koesoema) karakter didefinisikan sebagai ciri khas seseorang, berdasarkan hasil bentukan dari lingkungan sekitarnya ${ }^{8}$. Jadi, dapat disimpulkan karakter merupakan sifat bawaan seseorang yang menjadi ciri khasnya dan juga hasil dari bentukan lingkungan sekitarnya.

Lingkungan menjadi salah satu penentu dari sifat karakter seseorang. Dalam Sistem Pendidikan Nasional ada tiga lingkungan yang berperan dalam pembentukan karakter yaitu: 1) lingkungan keluarga, 2) Lingkungan sekolah, dan 3) Lingkungan masyarakat ${ }^{9}$. Dalam pelaksanaannya pendidikan karakter di sekolah tidak selalu menemui jalan yang mulus. Akan tetapi masih adanya bentuk-bentuk penyimpangan yang dilakukan oleh siswa, salah satunya permasalahan pendidikan karakter kedisiplinan di sekolah. Menurut Mustari (dalam Senja) mengartikan disiplin sebagai tindakan yang menunjukan perilaku tertib dan patuh pada berbagai ketentuan dan peraturan. Disiplin merupakan sebuah cara untuk membentuk perilaku anak melalui cara-cara yang tegas. Tegas disini bukan diartikan sebagai sifat yang otoriter ${ }^{10}$. Akan tetapi terkait dengan beberapa peraturan yang haruslah dipatuhi siswa dan guru sebagai role modelnya.

Dalam penelitian ini peneliti menemukan ada beberapa kasus penyimpangan dalam hal kedisiplinan yang dilakukan oleh siswa di SDIT Al-Zahira seperti terlambat datang ke sekolah, terlambat mengumpulkan tugas, keluar kelas sebelum waktunya istirahat, terlambat masuk kelas ketika sudah bel masuk, mengerjakan soal ujian tidak jujur. Beberapa kasus penyimpangan ini peneliti peroleh berdasarkan hasil dari wawancara yang dilakukan dengan wali kelas serta guru madrasah kelas 3 dan $4^{11}$. Serta penggunaan kuisioner yang sebelumnya telah diisi oleh oleh siswa kelas 3 dan 4 SDIT Al-Zahira.

\footnotetext{
${ }^{7}$ Majid, A., \& Andayani, D. Pendidikan Karkater Perspektif Islam, (Bandung: PT Remaja Rosdakarya, 2013).

${ }^{8}$ Koesoema, Doni. Pendidikan Karakter Strategi Mendidik Anak di Zaman Global. (Jakarta: Grasindo, 2011).

${ }^{9}$ Kemendiknas. Pengembangan Pendidikan Budaya dan Karakter Bangsa: Pedoman Sekolah. (Jakarta: Kemendiknas. 2010).

${ }^{10}$ Senja. Upaya Pembinaan Karakter Disiplin pada Anak Usia Sekolah Dasar Melalui Program Pembiasaan Salat Subuh Berjamaah. Skripsi. (Serang: Universitas Pendidikan Indonesia, 2015).

${ }^{11}$ Ade, iwan, Syifa dkk senin 7 juni 202110.00 WIB (wawancara)
} 
Dalam penelitian ini peneliti juga ditunjang oleh beberapa hasil penelitian terdahulu. yang mana penelitian ini dijadikan sebagai sumber acuan penguat dalam menentukan hasil penelitian serta sebagai bahan referensi peneliti. Seperti hasil penelitian dari Mas'at (2019) dengan penelitian yang berjudul "Pembentukan Karakter Disiplin Santri Melalui Amaliyah Yaumiyyah di Pondok Pesantren Al- Hikmah 2 Benda Sirampog Brebes". Dalam penelitiannya menghasilkan tiga poin utama, 1) unsur-unsur penunjangnya seperti (peraturan, hukuman, penghargaan, dan juga konsistensi). 2) indikator keberhasilan seperti (hadir tepat waktu, membiasakan aturan, dan menggunakan pakaian sesuai aturan). 3) kendala dalam proses pembiasaan tersebut yaitu: pengaruh lingkungan keluarga yang kurang begitu memperhatikan anaknya, kurangnya kesadaran siswa tentang pentingnya ilmu dan kedisiplinan, dan pengaruh lingkungan ${ }^{12}$.

Nugroho (2017) dalam penelitiannya yang berjudul "Pembentukan Karakter Disiplin Siswa Melalui Pembiasaan Salat Duha di SLB N Purbalingga". Hasil dari penelitian ini yaitu 1) salah satu upaya untuk membentuk karakter seseorang adalah dengan sebuah pembiasaan. 2) Sudah terjadi pembentukan karakter disiplin melalui pembiasaan salat duha yang telah dilakukan secara rutin dari tahun 2010. 3) disiplin yang terbentuk melalui pembiasaan salat duha ini adalah disiplin terhadap waktu dan peraturan yang berlaku di lingkungan sekolah. Sedangkan berdasarkan penelitian Nuryati (2018) "Pembiasaan Salat Berjamaah dalam Membentuk Karakter Disiplin Siswa SMA Negeri Piyungan Kabupaten Bantul" Hasil dari penelitian ini yaitu salat jemaah yang dilakukan di sekolah dapat membentuk karakter disiplin siswa SMA Negeri Piyungan Kabupaten Bantul ${ }^{13}$.

Berdasarkan beberapa hasil penelitian terdahulu tersebut menyebutkan bahwa adanya pembentukan sikap karakter disiplin berdasarkan pembiasaan ibadah yang dilakukan oleh siswa. Serta terdapat beberapa letak perbedan dari penelitian yang dilakukan oleh peneliti dengan penelitian sebelumnya, Yaitu pada penggunaan subjek

\footnotetext{
${ }^{12}$ Mas'at, B. A. S. “Pembentukan Karakter Disiplin Santri Melalui Amaliyah Yaumiyyah di Pondok Pesantren al Hikmah 2 Benda Sirampog Brebes". Disertasi Doktoral. (Malang: Universitas Islam Negeri Maulana Malik Ibrahim Malang, 2019).

${ }^{13}$ Nugroho, K. P. “Pembentukan Karakter Disiplin Siswa Melalui Pembiasaan Salat Dhuha SLB N Purbalingga Tahun Pelajaran 2016/2017". Disertasi Doktoral. (IAIN Purwokerto, Purwokerto,nu 2017)..
} 
penelitian, tempat penelitian, dan juga aspek teori acuan yang digunakan serta hasil dari rumusan masalah dalam penelitian. Adapun letak kebaruan dalam penelitian ini yaitu terletak pada hasil yang menunjukan adanya sikap disiplin hasil dari pembinaan melalui amaliyah yaumiyyah ibadah shalat siswa. Nilai-nilai pembinaan disiplin yang dimaksud yaitu berupa disiplin kebersihan, disiplin dalam waktu, disiplin dalam mengerjakan aturan, latihan kepemimpinan, dan latihan kebersamaan. Yang mana di penelitian sebelumnya belum ada yang menganalisis hasil temuannya mencakup ke lima nilai-nilai disiplin tersebut, dan juga hasil penelitian ini tentunya diperkuat dengan hasil uji kuisioner kepada siswa serta wawancara kepada guru.

Dalam mengatasi masalah tersebut, ada beberapa cara yang dapat dilakukan sebagai upaya pembentukan karakter disiplin pada siswa. Salah satunya yaitu melalui proses pembiasaan. di SDIT ALZahira ada sebuah pembiasaan ibadah sehari-hari yang biasa disebut amaliyah yaumiyyah. Amaliyah yaumiyyah secara bahasa terdiri dari dua kata, yaitu kata (عَمَلِيَّة) dalam bahasa Arab modern bermakna proses, atau pekerjaan/tindakan yang sedang berlangsung. Dan kata yaumiyyah yang berasal dari kata dasar (يومية) yang berarti hari. Dalam konteks ini lingkup dari kegiatan sehari-hari yang dimaksud dalam istilah Amaliyah yaumiyyah berkaitan dengan Sunnah harian berupa ibadah yang Nabi SAW lakukan. Menurut Widjaja (2020) terdapat sepuluh Sunnah Nabi yang dapat diamalkan oleh umat manusia dalam kehidupan sehari-hari, yaitu: Shalat duha, sedekah, shalat rawatib, qiyamul lail, puasa sunnah, dzikir pagi,shalat berjamaah di Masjid bagi laki-laki, baca Al-quran dan amalan sebelum tidur $^{14}$.

Berdasarkan paparan amalan sunnah yang dilakukan oleh Nabi tersebut Zuhri (dalam Widjaja) mendefinisikan Sunnah sebagai jalan hidup bagi siapa saja yang menjalaninya dengan jalan yang baik, maka dicatatkan baginya pahala begitu pula sebaliknya apabila melakukan keburukan akan menerima dosa ${ }^{15}$. Adapun menurut Soetari (dalam

\footnotetext{
${ }^{14}$ Widjaja, M. Y. A. (2020). Konsep Spiritual Leadership Menghidupkan Sunnah Harian Nabi Muhammad dalam Pembentukan Karakter SDI di Era Millenial. Saujana: Jurnal Perbankan Syariah dan Ekonomi Syariah, 2(1), 69-84.

${ }^{15}$ Widjaja, M. Y. A. (2020). Konsep Spiritual Leadership Menghidupkan Sunnah Harian Nabi Muhammad dalam Pembentukan Karakter SDI di Era Millenial. Saujana: Jurnal Perbankan Syariah dan Ekonomi Syariah, 2(1), 69-84.
} 
Widjaja) Sunnah merupakan segala sesuatu yang diriwayatkan dari Rasulullah SAW sebelum diangkat menjadi rasul maupun sesudahnya baik perkataan, perbuatan, atau persetujuan ${ }^{16}$

Dari beberapa ibadah Sunnah yang dilakukan oleh Nabi. Peneliti memfokuskan pembahasannya hanya pada ibadah shalat saja. di SDIT Al-Zahira ada beberapa ibadah shalat sehari-hari yang merupakan sebuah program pembiasaan. Kegiatan ini berupa kegiatan pembiasaan yang diterapkan sebagai proses pembinaan berupa pembentukan karakter disiplin pada siswa, seperti: salat fardu, salat tahajud, salat duha dan salat rawatib. Adapun untuk Kegiatannya sendiri dilakukan di sekolah dan juga di rumah. Serta dalam pelaksanannya ditunjang oleh lembar evaluasi ibadah siswa yaitu lembar mutaba'ah.

Penelitian ini menggunakan pendekatan kualitatif sedangkan untuk metodenya menggunakan metode studi kasus. Dalam pengumpulan data dipenelitian ini peneliti menggunakan triangulasi data yaitu wawancara semi terstuktur, yang ditujukan kepada kepala sekolah, 2 orang guru madrasah dan 2 guru kelas. Dokumentasi, dimana dokumentasi ini berbentuk lembar mutaba'ah siswa kelas 3 dan 4 SDIT Al-Zahira. Dan peneliti juga menggunakan kuisioner sebagai alat pengumpulan data yang telah dibagikan kepada 21 siswa SDIT AlZahira kelas 3 dan 4 . SDIT Al-Zahira merupakan tempat peneliti melakukan penelitian hal ini dikarenakan di SDIT Al-Zahira terdapat sebuah kasus berupa pembiasaan amaliyah yaumiyyah yang menjadi subjek dalam penelitian ini.

Dalam Teknik analisis datanya peneliti menggunakan pendapat menurut Miles \& Huberman (dalam Sugiyono) yang mana ada tiga tahapan, yang pertama pengumpulan data, yaitu peneliti mengumpulkan data yang ada di lapangan menggunakan instrument yang telah dipersiapkan sebelumnya. Dalam penelitian ini pengumpulan data menggunakan wawancara, kuesioner dan dokumentasi. Sealnjutnya Reduksi data, dimana mereduksi data berarti merangkum, memilih dan memilah halhal pokok, memfokuskan pada hal-hal yang penting dicari

\footnotetext{
${ }^{16}$ Widjaja, M. Y. A. (2020). Konsep Spiritual Leadership Menghidupkan Sunnah Harian Nabi Muhammad dalam Pembentukan Karakter SDI di Era Millenial. Saujana: Jurnal Perbankan Syariah dan Ekonomi Syariah, 2(1), 69-84.
} 
temanya dan polanya. Dan yang ketiga pemaparan data, peneliti memaparkan data hasil dari analisis data yang telah dipilah-pilah pada tahap sebelumnya. Dan yang terkahir penarikan kesimpulan, dimana peneliti melakukan penarikan kesimpulan berdasarkan data yang telah diperoleh lalu mendiskripsikannya serta hasilnya divalidasi oleh ahli ${ }^{17}$.

\section{Hasil dan Pembahasan}

Amaliyah yaumiyyah merupakan ibadah sehari-hari yang dilakukan oleh umat muslim. Dimana ibadah ini merupakan sebuah proses penghambaan seorang makhluk kepada sang pencipta yaitu allah SWT. Hal ini selaras dengan pendapat yang dikemukakan oleh Jenuri, Rohendi \& Rohayati bahwa ibadah yaitu bentuk penghambaan manusia terhadap Allah SWT untuk mendekatkan diri dan sebagai bentuk realisasi dalam pelaksanaan kewajiban selaku mahluk ciptaan Allah $^{18}$. Selanjutnya, dilengkapi oleh Shiddiqy (dalam Halimah) bahwa ibadah merupakan bentuk ketaatan yang manusia kerjakan untuk mengharap ridho serta pahala dari Allah SWT ${ }^{19}$.

Dalam pelaksanaannya amaliyah yaumiyyah ini banyak sekali jenisnya, akan tetapi dalam penelitian ini peneliti memfokuskan pada ibadah salat saja. Salat yang dimaksud dalam penelitian ini yaitu seperti: salat fardhu, salat sunnah rawatib, salat duha, dan salat tahajud. Karena salat juga merupakan salah satu bentuk dari amaliyah yaumiyyah. Pengerucutan ini dilatarbelakangi berdasarkan kasus yang peneliti teliti di SDIT Al-Zahira yaitu tentang implementasi amaliyah yaumiyyah dalam pembinaan karakter disiplin siswa.

1. Pelaksanaan Pembiasaan Amaliyah yaumiyyah di SDIT Al-Zahira

Program pembiasaan amaliyah yaumiyyah ini sudah berjalan sekitar 4 tahun terakhir semenjak didirikannya SDIT Al-Zahira. Program ini merupakan sebuah pembiasaan ibadah salat sehari-

\footnotetext{
${ }^{17}$ Sugiyono. Metode Penelitian Kualitatif Untuk Penelitian Yang Bersifat: Eksploratif, Enterpretif, Interaktif, dan Konstruktif, (Bandung: Alfabeta, 2017)..

${ }^{18}$ Jenuri, Rohendi, E., Rohayati, R. Pendidikan Agama Islam Mengokohkan Karakter Calon Guru Profesional. (Bandung: Rizqi Press, 2017).

${ }^{19}$ Halimah, N. N. "Pengaruh Pengamalan Ibadah Salat Berjamaah Terhadap Kedisiplinan Santri Kelas IV di Madrasah Diniyah Miftahul Ulum Tlutup Trangkil Pati", Disertasi Doktoral, (Kudus: IAIN Kudus, 2020).
} 
hari siswa. Adapun pembiasaan ibadah ini bertujuan agar siswa memiliki rasa kesadaran diri kepada sang pencipta, kedisiplinan untuk melakukan ibadah, dan juga supaya siswa menjadi pribadi yang kuat dalam iman dan taqwanya. Terlepas dari tujuan sekolah tersebut program pembiasaan ini sebagai salah satu bentuk pembinaan karakter pada siswa. Asumsi tersebut berdasarkan penuturan hasil wawancara yang dilakukan dengan ibu kepala sekolah dan guru SDIT Al-Zahira ${ }^{20}$.

Program pembiasaan ibadah sehari-hari atau amaliyah yaumiyyah ini dalam pelaksanaannya dilakukan di rumah dan di sekolah. Adapun untuk kegiatan amaliyah yaumiyyah yang dilakukan di sekolah yaitu salat duha berjamaah dan salat dzuhur berjamaah. Untuk kegiatan amaliyah yaumiyyah lainnya dilakukan di rumah siswa masing-masing. Dari adanya kegiatan pembiasaan yang dilakukan di rumah akhirnya sekolah mempelopori kerjasama dengan wali murid, karena guru tidak dapat memantau secara langsung. Hal ini juga merupakan salah satu bentuk dukungan dalam menyukseskan program sekolah berupa pembiasaan amaliyah yaumiyyah siswa. Berikut merupakan dokumentasi dari amaliyah yaumiyyah siswa yang dilakukan di rumah dan juga di sekolah.

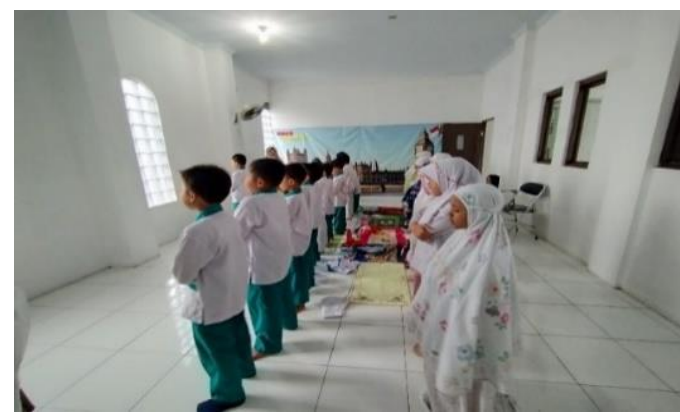

Gambar 4.1

Siswa yang Melakukan

Amaliyah yaumiyyah di Sekolah

${ }^{20} \mathrm{Ibu}$ kepala sekolah jum'at 18 juni 13.00 WIB (wawancara) 


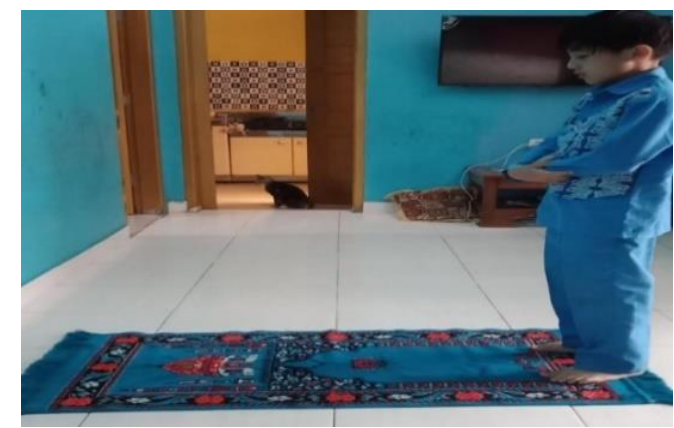

Gambar 4.2

Siswa yang Melakukan

Amaliyah yaumiyyah di Rumah

Pembentukan program pembiasaan tidak terlepas dari Visi dan Misi yang ada di SDIT Al-Zahira. Yaitu "Beriman, Berilmu, dan Beramal". Berdasarkan wawancara dengan kepala sekolah beliau menuturkan dari Visi dan Misi tersebut terdapat tujuan yang diharapkan sekolah terhadap siswa SDIT Al-Zahira yaitu siswa ke depannya memiliki keimanan yang kokoh terhadap agama yang dianutnya. Di samping itu siswa juga memiliki ilmu yang dapat diamalkan ${ }^{21}$.

Pelaksaannya program pembiasaan amaliyah yaumiyyah ditunjang oleh lembar mutaba'ah. Lembar mutaba'ah sendiri merupakan lembar evaluasi ibadah yang sekolah buat untuk diberikan kepada siswa, yang mana di dalamnya memuat kolom berupa tabel ibadah-ibadah yang akan dikerjakan oleh siswa. Seperti ibadah salat fardhu, salat sunnah rawatib, salat tahajud dan juga salat duha. Lembar ini biasanya diberikan setiap sebulan atau dua minggu sekali kepada siswa.

Dalam pengisiannya siswa cukup dengan menyeklis atau menyilang kolom ibadah yang tersedia. Berdasarkan pemaparan wali madrasah keterangan menyeklis dan menyilang di lembar mutaba'ah sebagai berikut: Jika siswa mengisi dengan menyeklisnya, berarti siswa tersebut mengerjakan ibadah salat di hari itu. Akan tetapi jika siswa

${ }^{21} \mathrm{Ibu}$ kepala sekolah jum'at 18 juni 13.00 WIB (wawancara) 
mengisi dengan silang, berarti siswa tersebut tidak mengerjakan ibadah salat di hari itu. Berikut merupakan contoh format dari lembar mutaba'ah siswa.



Gambar 4.3

\section{Contoh Lembar Mutaba'ah}

Metode pembelajaran program pembiasaan amaliyah yaumiyyah dilakukan dengan cara perulangan, hal ini memanglah sangat cocok diterapkan kepada siswa Sekolah Dasar. Karena menurut Majid \& Andayani pendidikan yang dilakukan secara berulangkali dirasa sangat efektif karena anak akan menjadi lebih paham ${ }^{22}$. Pengulangan juga menjadikan apa yang disampaikan atau diajarkan dapat tersimpan dalam memorinya lebih lama.

Untuk kegiatan amaliyah yaumiyyah yang dilakukan di sekolah salah satunya salat duha. Rangkaian kegiatan salat duha biasanya ada persiapan dan pelaksanaan. Dari kegiatan persiapan ini berdasarkan analisis peneliti terdapat sebuah penerapan nilai disiplin waktu dan nilai disiplin peraturan. Hal ini tercermin pada saat siswa datang ke sekolah dan juga

${ }^{22}$ Majid, A., \& Andayani, D. Pendidikan Karkater Perspektif Islam, (Bandung: PT Remaja Rosdakarya, 2013). 
menaruh tas ke kelas lalu langsung bersiap-siap melaksanakan salat duha. Serta disiplin terhadap kebersihan juga terdapat dalam persiapan sebelum melaksanakan ibadah salat yaitu ketika siswa berwudu terlebih dahulu.

Proses pelaksanaan salat duha berjamaah didampingi oleh wali kelas dan wali madrasah. Fungsi dari guru yaitu untuk mengawasi jalannya salat duha, dan sebagai pengkondisi siswa yang tidak serius dalam salat. Sikap memposisikan sebagai pengawas dan pengkondisi yang dilakukan oleh guru merupakan strategi dalam penanaman kedisiplinan, terutama dalam ibadah yaitu dengan menemani atau mendampingi siswa. Hal ini selaras Zuhaili (dalam Maulana) yang mana menyebutkan bahwa siswa masih sangat membutuhkan bimbingan dan arahan guru ${ }^{23}$.

Jajaran shaf dalam salat duha berjamaah posisi laki-laki berada dipaling depan dan perempuan di belakang laki-laki. Pembacaan doa-doa di dalam salat duha tersebut masih dijaharkan dalam artian masih dilafalkan dengan nyaring karena sebagai bahan belajar siswa. Hal ini bertujuan juga untuk mengulang-ulang bacaan, sehingga menjadi sebuah pembiasaan supaya tidak hilang hafalnnya.

Salat duha ini dilakukan berjamaah dengan dipimpin oleh imam, dan yang menjadi Imam yaitu siswa laki-laki yang hari itu bertugas menjadi imam. Adanya seorang imam dalam salat duha berjamaah terdapat sebuah bentuk pembinaan nilai disiplin di dalamnya yaitu latihan kepemimpinan. Menurut syarbini (dalam Islamiyah) bahwa adanya imam dan makmum di dalam shalat berjamaah, mencerminkan adanya sikap kepemimpinan ${ }^{24}$.

di SDIT Al-Zahira terdapat sebuah sistem hukuman yang diterapkan kepada siswanya jika ada yang tidak melaksankan amaliyah yaumiyyah. Hukuman ini biasa disebut

\footnotetext{
${ }^{23}$ Maulana, F. "Penanaman Kedisiplinan pada Siswa Melalui Ibadah Praktis di SD Birrul Walidain Muhammadiyah Sragen", Disertasi Doktoral, (Yogyakarta: Universitas Muhammadiyah Surakarta, 2002).

${ }^{24}$ Islamiyah, I. "Penanaman Nilai Kedisiplinan Melalui Pembiasaan Salat Zuhur Berjamaah Siswa Kelas VII SMP N 2 Kec. Suruh Kab. Semarang Tahun Pelajaran 2017/2018", Disertasi Doktoral, (Semarang: IAIN Salatiga, 2018)
} 
dengan istilah $i q o b$. Ada beberapa jenis iqob yang diberlakukan di SDIT Al-Zahira yaitu sebagai berikut: membaca istighfar, hafalan surah pendek, diberikan peringatan, dan pengurangan nilai.

Penerapan iqob ini juga sebagai salah satu bentuk pengambilan sikap terhadap pembentukan karakter disiplin siswa. Hal ini sejalan dengan pendapat Novitasari bahwa pemberian hukuman kepada siswa dalam rangka mendidik sangat berperan penting dikarenakan jika pendidikan yang dilakukan terlalu lembut akan menjadikansiswa kurang disiplin serta tidak adanya sikap keteguhan hati ${ }^{25}$. Berdasarkan analisis peneliti bahwa penerapan iqob ini merupakan salah satu bentuk sikap pembinaan disiplin beribadah.

Selain salat duha, pembiasaan amaliyah yaumiyyah yang dilakukan di sekolah yaitu salat dzuhur berjamaah. Salat dzuhur berjamaah di sekolah dilakukan ketika sudah memasuki waktu salat dzuhur. Ketika sudah memasuki waktu dzuhur siswa langsung mengambil air wudu dan melakukan salat dzuhur bersama-sama di aula. Pelaksanaan salat dzuhur dilakukan hampir sama dengan salat duha, yaitu didampingi oleh guru.

Untuk shaf dalam salat dzuhur berjamaah posisi lakilaki berada dipaling depan dan perempuan di belakang mengikuti shaf laki-laki. Pengaturan shaf atau barisan ketika salat ini di dalamnya terdapat sebuah pembinaan karakter disiplin terhadap siswa berupa penanaman nilai disiplin dalam peraturan. Karena diharuskan lurus, rapih, serta tertib.

Pelaksanaan yang dilakukan secara berjamaah merupakan salah satu bentuk penanaman nilai disiplin dalam kebersamaan. Terlepas dari itu pelaksanaan salat dari awal gerakan salat sampai dengan salam dilakukan secara berurutan, yang mencerminkan adanya sebuah sikap pembinaan nilai disiplin terhadap aturan yang harus ditegakan.

${ }^{25}$ Novitasari, A. Pemberian Reward and Punishment dalam Membentuk Karakter Disiplin Anak pada Sekolah Madrasah Ibtidaiyah. Halaqa: Islamic Edication Journal 3, No.1 (2019): 27-33.

https://doi.org/10.21070/halaqa.v3i1.2113 
Selanjutnya untuk kegiatan pembiasaan amaliyah yaumiyyah yang dilakukan di rumah, sekolah menjalin kerjasama dengan wali murid. Bentuk kerjasama ini dijalin antara wali murid dengan wali madrasah, dikarenakan yang bertanggung jawab pada pembiasaan ini yaitu wali madrasah. Berdasarkan wawacara yang dilakukan dengan wali madrasah bahwa bentuk dari koordinasi yang dibangun dengan wali murid yaitu berupa komunikasi melalui grup whatsapp dan pada saat pembagian rapot. Komunikasi yang dibangun antara wali madrasah dan wali murid biasanya membahas tentang perkembangan siswa dan kendala yang dialami wali murid dalam melakukan pendampingan di rumah.

Program amaliyah yaumiyyah yang dilakukan di rumah oleh siswa yaitu berupa salat ashar, salat maghrib, salat isya, salat subuh, salat tahajud, dan salat rawatib. Amaliyah yaumiyyah berupa ibadah salat yang dilakukan oleh siswa ini dilaksanakan sesuai dengan waktu pengerjaan salat tersebut. Selain amaliyah yaumiyyah dalam pengerjaan salat fardhu, ada juga 2 salat sunnah lainnya yaitu salat sunnah rawatib dan juga salat sunnah tahajud.

Berdasarkan pengerjaan salat yang dilakukan berlainan waktu sesuai dengan pelaksanaannya, hal ini menunjukan adanya bentuk pembinaan dalam hal disiplin terhadap waktu. Ketika siswa akan melaksanakannya haruslah bersuci terlebih dahulu yaitu dengan berwudu, hal ini menunjukan adanya bentuk dari pembinaan nilai disiplin terhadap kebersihan. Belum lagi ketika harus menaati segala aturan di dalam salat yang mencerminkan pembinaan terhadap aturan yang berlaku.

Ketika kegiatan amaliyah yaumiyyah ini dilakukan di rumah dan guru tidak bisa memantau kegiatan tersebut secara langsung, maka orang tua yang berkewajiban membimbing siswa. Menurut penuturan ibu kepala sekolah orang tua juga harus mendokumentasikan ketika anaknya sedang melakukan ibadah dan mengirimkannya ke wali madrasah. Hal ini sebagai salah satu upaya sekolah untuk terus melaksanakan program pembiasaan ini dengan baik. Program amaliyah yaumiyyah ini masih berlangsung dan berjalan dengan lancar walaupun di masa pandemi. 
2. Metode Apa yang Digunakan Penanaman Sikap Disiplin dalam Pembiasaan Amaliyah yaumiyyah di SDIT Al-Zahira.

SDIT Al-Zahira dalam pembinaan karakter disiplin siswa memberlakukan beberapa metode berdasarkan analisis hasil wawancara yang telah peneliti lakukan terhadap guru dan kepala sekolah sebagai berikut:

a. Tunjukan teladan, biasanya dilakukan dengan mencontohkan teman yang rajin atau melalui pemberian kisah-kisah Nabi SAW.

b. Dorongan (pemberian motivasi), berupa kata-kata mutiara. Menurut Majid \& Andayani dorongan yang diberikan akan menjadikan sebuah kekuatan seseorang dalam mencapai sebuah tujuan ${ }^{26}$.

c. Kontinuitas, Program yang dilakukan secara terus menerus berlanjut dari mulai kelas 1 sampai dengan kelas tinggi.

d. Pengulangan, adanya pengulangan setiap hari dalam kegiatan pembiasaan. Majid \& Andayani menuturkan bahwa dengan adanya pengulangan siswa akan lebih cepat mengerti dan menjadi salah satu cara efektif dilakukan ${ }^{27}$.

e. Arahkan bimbingan, Hal ini terlihat di dalam pendampingan guru terhadap siswa dalam melakukan pembiasaan ibadah amaliyah yaumiyyah.

3. Faktor Pendukung dan Penghambat Kedisiplinan Pembiasaan Amaliyah yaumiyyah di SDIT Al-Zahira

Dalam proses pelaksanaan pembiasaan amaliyah yaumiyyah ada dua faktor yang menjadi pengaruh terhadap jalannya program pembiasaan tersebut. Seperti faktor pendukung dan faktor penghambat.

\section{a. Faktor Pendukung}

Berikut merupakan beberapa faktor pendukung disiplin siswa dalam pembiasaan amaliyah yaumiyyah di SDIT Al-Zahira.

\footnotetext{
${ }^{26}$ Majid, A., \& Andayani, D. Pendidikan Karkater Perspektif Islam, (Bandung: PT Remaja Rosdakarya, 2013).

${ }^{27}$ Majid, A., \& Andayani, D. Pendidikan Karkater Perspektif Islam, (Bandung: PT Remaja Rosdakarya, 2013).
} 
1) Visi dan Misi SDIT Al-Zahira

Dimana dalam visi dan misi tersebut memuat tujuan sekolah dan direalisasikan melalui program-program yang ada salah satunya pembiasaan amaliyah yaumiyyah ini yang didalamnya memuat pembinaan-pembinaan karakter, Seperti salah satunya yaitu karakter disiplin.

2) Peran guru dalam membeimbing siswa

Peran Wali kelas dalam proses pembiasan ini yaitu sebagai pembimbing dan pengawas dalam jalannya proses pembiasaan amaliyah yaumiyyah ketika di sekolah. Sedangkan peran wali madrasah juga hampir sama dengan wali kelas ketika pelaksanaan program amaliyah yaumiyyah di sekolah. Akan tetapi dalam program pembiasaan ini wali madrasah lah yang memegang tanggung jawab penuh. Seperti dalam pengumpulan lembar mutaba'ah dan mengontrol jalannya pembiasaan amaliyah yaumiyyah terutama ketika di rumah.

3) 3) Kerja sama antara guru dan Orang Tua

Ibu kepala sekolah menuturkan bahwa keluarga sebagai support sistem terbesar sehingga program sekolah ini dapat terlaksana dengan disiplin. Dalam pelaksanaannya kerja sama antara sekolah dengan orang tua terbangun melalui koordinasi satu sama lain salah satunya dalam program pembiasaan ini. Hal ini ditunjang berdasarkan hasil wawancara dengan Mr. iwan yang menjelaskan bahwa koordinasi yang dibangun antara sekolah dengan orang tua melalui WhatsApp grup dan juga langsung ketika pembagian rapot. Komunikasi yang dijalin biasanya terkait dengan hambatan atau perkembangan dari siswa dalam program pembiasaan di rumah ${ }^{28}$.

Ketika melaksanakan program pembiasaan di rumah orang tua mendampingi dan biasanya mengirimkan bukti foto ibadah siswa ke wali madrasah. Dari paparan tersebut peran orang tua juga sangat berpengaruh sekali

${ }^{28}$ Iwan jum'at 7 juni 11.00 WIB (wawancara) 
terhadap pembentukan karakter disiplin anak terutama melalui program pembiasaan amaliyah yaumiyyah.

b. Faktor Penghambat

Berikut merupakan beberapa faktor penghambat disiplin siswa dalam pembiasaan amaliyah yaumiyyah di SDIT Al-Zahira berdasarkan hasil wawancara yang peneliti lakukan.

1) Rasa Malas Siswa

Menurut penuturan Wali Madrasah kelas 3, faktor yang menjadi penghambat disini salah satunya rasa malas siswa. Ada beberapa siswa yang tidak mengumpulkan lembar mutaba'ah padahal sekolah sudah menentukan batas pengumpulannya. Hal ini sebagai gambaran bahwa adanya hambatan dalam kedisiplinan yaitu dalam aturan.

Rasa malas ini berasal dari dalam siswa atau disebut faktor intern yang menghambat dalam diri siswa. Faktor intern selaras dengan bentuk kesadaran. Dimana faktor kesadaran yitu berupa hati dan pikiran yang telah terbuka tentang apa yang telah dikerjakan. Sehingga disiplin akan lebih mudah diimplementasikan jika dengan kesadaran sendiri tanpa ada unsur paksaan dari pihak lain.

2) Kesibukan Orang Tua

Faktor kesibukan orang tua juga menjadi salah satu penghambat dalam pembentukan disiplin siswa. Salah satu faktor penghambat dari pembentukan karakter pada anak yaitu lingkungan. lingkungan merupakan suatu perangkat yang sangat besar pengaruhnya terhadap perkembangan anak. Ada tiga lingkungan yang sebagaimana kita tahu. Lingkungan keluarga, sekolah dan juga masyarakat.

4. Sanksi Bagi Siswa yang Tidak Melakukan Amaliyah yaumiyyah Dalam penanaman karakter disiplin siswanya, SDIT ALZahira menerapkan beberapa sistem hukuman terutama jika melakukan pembiasaan ibadah amaliyah yaumiyyah. Hukuman diberikan karena ada pelanggaran atau berlawanan. Hukuman 
berfungsi untuk menghalangi pengulangan pelanggaran, mendidik, dan memberi motivasi untuk menghindari perilaku yang tidak diterima oleh masyarakat. Pemberian hukuman ini juga dapat diartikan sebagai pemberian peringatan atau punishment.

Pemberian punishment, tidak serta merta diberikan. Akan tetapi dalam pemberian punishment. harus juga memperhatikan situasi dan kondisi serta pemberiannya pun dilakukan sesuai dengan kebutuhan. di SDIT Al-Zahira juga menerapkan sistem punishment yang dikenal dengan istilah Iqob. Ibu kepala sekolah menjelaskan dalam penerapannya iqob sendiri tidak dilakukan dengan menggunakan kekerasan fisik dan bentuk kekerasan lainnya. Akan tetapi dilakukan secara verbal dan non verbal seperti teori yang sudah dijelaskan sebelumnya. Berdasarkan hasil wawancara yang telah dilakukan kepada guru dan kepala sekolah berikut adalah beberapa bentuk iqob verbal dan non verbal yang diterapkan di SDIT Al-Zahira sebagai berikut:

a. Membaca istighfar, siswa membaca istighfar dan disetorkan kepada guru sesuai jumlah kelipatan istighfar yang terakhir kali disetorkan.

b. Hafalan surah pendek, Siswa menghafalkan surah tertentu yang ditunjuk oleh wali kelas dan nantinya akan disetorkan ke wali madrasah. Dalam hal ini antara wali madrasah dan wali kelas saling koordinasi satu sama lain.

c. Diberikan peringatan, dalam pelaksanaanya siswa diberikan peringatan secara lisan dan diberikan motivasi serta nasehat supaya lebih giat lagi dalam melaksanakan ibadah.

d. Pengurangan nilai, hal ini dikarenakan proses pembiasaan amaliyah yaumiyyah ini dilakukan penilaian secara berkala dan diakhir pembelajaran akan diakumulasikan dengan penilaian yang lain sebagai nilai tambah mata pelajaran agama.

Berdasarkan sistem iqob yang diberlakukan di SDIT AlZahira penting sekali diterapkan. Penerapan iqob ini juga sebagai salah satu bentuk pengambilan sikap terhadap pembentuk karakter disiplin siswa. 
5. Implikasi Amaliyah yaumiyyah Terhadap Pembinaan Karakter Disiplin Siswa SDIT Al-Zahira

Setiap suatu program yang dirancang oleh lembaga sekolah tertentu pastilah memiliki sebuah tujuan. Tujuan yang dimaksud biasanya berupa implikasi atau pengaruhnya bagi orang yang menjadi sasaran objek dari program tersebut. Begitupun dengan program pembiasaan amaliyah yaumiyyah di SDIT Al-Zahira. Untuk mengetahui sejauh mana program pembiasaan ini memiliki implikasi terhadap pembinaan karakter siswa, peneliti melakukan pengumpulan data melalui pengisian kuesioner atau angket. Yang mana subjek dalam penelitian ini yaitu siswa kelas 3 dan kelas 4 SDIT Al-Zahira. Terhitung ada 21 responden yang mengisi kuisioner yaitu 13 responden dari kelas 3 dan 8 responden dari kelas 4 .

Kuesioner tersebut terdiri dari 20 pernyataan, positif dan negatif. Adapun jenis kuesioner yang digunakan merupakan kuesioner tertutup dengan 4 alternatif jawaban selalu, sering, kadang-kadang dan tidak pernah. Kemudian kuesioner ini dibuat oleh peneliti berdasarkan hasil dari nilai-nilai kedisiplinan yang tertanam dalam proses menjalankan amaliyah yaumiyyah yaitu ibadah salat. Selanjutnya di bawah ini merupakan hasil dari kuisioner yang telah diisi oleh siswa kelas 3 dan 4 SDIT Al-Zahira yang menjadi subjek penelitian sebanyak 21 responden pada tanggal 23 juni sampai 30 juni 2021. berikut hasil rekapitulasi kuesioner tersebut.

Tabel 4.1

Hasil Rekapitulasi Kuesioner

\begin{tabular}{|l|l|c|c|c|c|c|c}
\hline \multirow{2}{*}{ No } & \multicolumn{3}{|l|}{ Pertanyaan } & \multicolumn{3}{|c|}{ Jawaban Siswa (\%) } & \multicolumn{3}{c}{ Respon Siswa (\%) } \\
\cline { 2 - 8 } & & S & SR & KD & TP & Tepat & Tidak \\
\hline 1. & $\begin{array}{l}\text { Saya datang ke sekolah } \\
\text { tepat waktu }\end{array}$ & 47.6 & 38.1 & 9.5 & 4.8 & 85.7 & 14.3 \\
\hline 2. & $\begin{array}{l}\text { Saya membuang sampah } \\
\text { tidak pada tempatnya }\end{array}$ & 9.5 & 0 & 33.3 & 57.1 & 90.1 & 9.5 \\
\hline
\end{tabular}




\begin{tabular}{|c|c|c|c|c|c|c|c|}
\hline 3. & $\begin{array}{l}\text { Ketika mendengar adzan } \\
\text { saya langsung mengambil } \\
\text { wudu bersiap untuk salat }\end{array}$ & 23.8 & 42.9 & 33.3 & 0 & 66.7 & 33.3 \\
\hline 4. & $\begin{array}{l}\text { Saya suka berbicara kotor } \\
\text { kepada teman }\end{array}$ & 0 & 0 & 9.5 & 90.5 & 100 & 0 \\
\hline 5. & $\begin{array}{l}\text { Saya mengerjakan tugas } \\
\text { yang diberikan oleh guru }\end{array}$ & 66.7 & 19 & 14.3 & 0 & 85.7 & 14.3 \\
\hline 6. & $\begin{array}{l}\text { Saya terlambat masuk } \\
\text { kelas ketika istirahat sudah } \\
\text { selesai }\end{array}$ & 0 & 4.8 & 33.3 & 61.9 & 95.2 & 4.8 \\
\hline 7. & $\begin{array}{lrr}\text { Saya tidak } & \text { akan } \\
\text { meninggalkan } & \text { sekolah } \\
\text { sebelum jam } & \text { sekolah } \\
\text { berakhir } & & \\
\end{array}$ & 61.9 & 0 & 0 & 38.1 & 61.9 & 38.1 \\
\hline 8. & $\begin{array}{l}\text { Saya suka menunda- } \\
\text { menunda salat }\end{array}$ & 0 & 9.5 & 66.7 & 23.8 & 90.5 & 9.5 \\
\hline 9. & $\begin{array}{lll}\text { Saya berbicara } & \text { sopan } \\
\text { dengan orang tua } & \\
\end{array}$ & 71.4 & 23.8 & 4.8 & 0 & 95.2 & 4.8 \\
\hline 10. & $\begin{array}{l}\text { Saya dihukum karena } \\
\text { tidak mengerjakan tugas }\end{array}$ & 4.8 & 4.8 & 38.1 & 52.4 & 90.5 & 9.6 \\
\hline 11. & $\begin{array}{l}\text { Saya melaksanakan salat } \\
\text { lima waktu setiap hari }\end{array}$ & 47.6 & 19 & 33.3 & 0 & 66.6 & 33.3 \\
\hline 12. & $\begin{array}{l}\text { Saya memakai seragam } \\
\text { tidak sesuai aturan }\end{array}$ & 4.8 & 0 & 9.5 & 85.7 & 95.2 & 4.8 \\
\hline 13. & $\begin{array}{l}\text { Saya mengumpulkan } \\
\text { tugas tepat waktu }\end{array}$ & 33.3 & 19 & 47.6 & 0 & 52.3 & 47.6 \\
\hline 14. & $\begin{array}{l}\text { Saya tidak suka } \\
\text { mendengarkan } \\
\text { orang tua }\end{array}$ & 0 & 0 & 42.9 & 57.1 & 100 & 0 \\
\hline 15. & $\begin{array}{l}\text { Saya tidak mencontek } \\
\text { ketika ulangan }\end{array}$ & 42.9 & 0 & 19 & 38.1 & 42.9 & 57.1 \\
\hline 16. & $\begin{array}{l}\text { Saya bermain di luar kelas } \\
\text { sebelum } \\
\text { istirahat }\end{array}$ & 4.8 & 0 & 9.5 & 85.7 & 95.2 & 4.8 \\
\hline 17. & $\begin{array}{l}\text { Saya membuat surat ijin } \\
\text { ketika tidak hadir ke } \\
\text { sekolah }\end{array}$ & 66.7 & 14.3 & 9.5 & 9.5 & 81 & 19 \\
\hline
\end{tabular}




\begin{tabular}{|l|l|c|c|c|c|c|c|}
\hline 18. & $\begin{array}{l}\text { Saya malas bangun ketika } \\
\text { salat subuh }\end{array}$ & 4.8 & 23.8 & 42.9 & 28.6 & 71.5 & 28.6 \\
\hline 19. & $\begin{array}{l}\text { Saya memerhatikan guru } \\
\text { yang sedang menjelaskan } \\
\text { materi pelajaran }\end{array}$ & 71.4 & 19 & 9.5 & 0 & 90.4 & 9.5 \\
\hline $\begin{array}{l}\text { 20. } \\
\begin{array}{l}\text { Saya lebih suka main game } \\
\text { dari pada belajar }\end{array}\end{array}$ & 4.8 & 14.3 & 57.1 & 23.8 & 80.9 & 19.1 \\
\hline Jumlah & $\mathbf{5 6 6 . 8}$ & $\mathbf{2 5 2 . 3}$ & $\mathbf{5 2 3 . 6}$ & $\mathbf{6 5 7 . 1}$ & $\mathbf{1 6 3 7 . 5}$ & $\mathbf{3 6 2}$ \\
\hline Jumlah Responden Tepat & & & $\mathbf{1 6 3 7 . 5}$ & \\
\hline Jumlah Responden Tidak Tepat \\
\hline Rata-rata
\end{tabular}

Dari tabel hasil rekapitulasi kuesioner tersebut dapat diketahui bahwa adanya implikasi dari pembinaan amaliyah yaumiyyah terhadap sikap disiplin siswa di SDIT Al-Zahira. Hal tersebut dibuktikan berdasarkan hasil rata-rata keseluruhan poin yang menunjukan bahwa $81.9 \%$ siswa sudah menjawab dengan tepat. Berdasarkan hasil presentase tersebut berarti sudah tertanamnya nilai kedisiplinan terhadap siswa melalui pembinaan berupa pembiasaan amaliyah yaumiyyah.

Berdasarkan analisis peneliti terhadap hasil presentase angket diatas terdapat beberapa aspek disiplin yang sangat menonjol dan juga ada yang masih kurang sehingga perlu ditingkatkan lagi. Hasil angket ini menunjukan bahwa pembiasaan amaliyah yaumiyyah di SDIT AlZahira ini mempunyai dampak yang sangat besar pada sikap siswa, hal ini tercermin berdasarkan aspek disiplin dalam bersikap yang termuat dalam pernyataan nomor 9, 19, 4 dan 14. Untuk aspek disiplin terhadap waktu, disiplin peraturan, dan belajar yaitu hasilnya memiliki peranan yang bisa dibilang besar dalam pembinaan karakter disiplin siswa akan tetapi ada beberapa hasil presentase yang masih belum menonjol pada hasil presentase pernyataannya. Sedangkan dari pembiasaan amaliyah yaumiyyah ini berdasarkan hasil angket di atas menunjukan bahwa aspek disiplin beribadah dampaknya kepada siswa masih terbilang redah dibandingkan dengan ke 4 aspek lainnya. hal ini tercermin berdasarkan hasil presentase dari pernyataan nomor 3, 8, 11, dan 18. 


\section{Kesimpulan}

Berdasarkan hasil penelitian yang peneliti lakukan mengenai implementasi amaliyah yaumiyyah dalam pembinaan karakter disiplin siswa di SDIT Al-Zahira kelas 3 dan kelas 4, maka dapat peneliti simpulkan bahwa.

1. Proses pelaksanaan amaliyah yaumiyyah di SDIT Al-Zahira, dilaksanakan setiap hari, yaitu di rumah dan juga di sekolah. Pembiasaan ini berupa ibadah salat sehari-hari seperti: salat fardu, salat tahajud, salat duha, dan salat sunah rawatib. Adapun kegiatan pembiasaan amaliyah yaumiyyah yang dilaksanakan di sekolah yaitu salat duha dan juga salat dzuhur saja, sedangkan ibadah salat yang lainnya dikerjakan di rumah masing-masing. Untuk pembiasaan yang dilakukan di rumah wali madrasah bekerjasama dengan wali murid. Hal ini bertujuan untuk mendampingi dan memantau jalannya ibadah siswa, yaitu dengan mengirimkan bukti foto kegiatan ibadah siswa kepada wali madrasah masing-masing setiap harinya.

Disamping itu kegiatan ini ditunjang dengan adanya lembar evaluasi ibadah siswa, yaitu lembar mutaba'ah. Lembar ini berisi kolom ibadah yang diisi oleh siswa dan dikumpulkan kepada wali madrasah masing-masing setiap dua minggu sekali atau satu bulan sekali. Tujuan dari diadakannya pembinaan berupa pembiasaan amaliyah yaumiyyah ini yaitu diharapkan siswa memiliki kesadaran diri kepada sang pencipta dan juga kedisiplinan untuk melakukan ibadah agar mereka menjadi pribadi yang lebih kuat perihal iman dan taqwanya.

Selain itu ada beberapa nilai-nilai pembinaan disiplin yang tercermin dari hasil pembiasaan amaliyah yaumiyyah. Hal ini didasarkan hasil wawancara yang peneliti lakukan sebelumnya dengan guru dan juga kepala sekolah SDIT Al-Zahira serta berdasarkan hasil analisis hasil wawancara peneliti terhadap proses pelaksanaan amaliyah yaumiyyah berupa ibadah salat siswa. Nilai-nilai pembinaan disiplin tersebut yaitu berupa disiplin kebersihan, disiplin dalam waktu, disiplin dalam mengerjakan aturan, latihan kepemimpinan, dan latihan kebersamaan.

2. Implikasi dari proses pembinaan sikap karakter disiplin siswa melalui pembiasaan amaliyah yaumiyyah ini di buktikan dari hasil pengisian kuesioner oleh 21 responden kelas 3 dan 4 di SDIT Al- 
Zahira, dan menghasilkan presentase $81,9 \%$ siswa menjawab dengan tepat dan $18,1 \%$ siswa menjawab tidak tepat atas 20 pernyataan yang terdiri dari 10 pernyataan positif dan 10 pernyataan negatif. Sehingga dapat disimpulkan bahwa adanya implikasi dari program pembiasaan amaliyah yaumiyyah yang dilaksanakan di SDIT Al-Zahira terhadap pembinaan sikap disiplin siswa.

\section{Daftar Pustaka}

Halimah, N. N. "Pengaruh Pengamalan Ibadah Salat Berjamaah Terhadap Kedisiplinan Santri Kelas IV di Madrasah Diniyah Miftahul Ulum Tlutup Trangkil Pati", Disertasi Doktoral, (Kudus: IAIN Kudus, 2020).

Islamiyah, I. "Penanaman Nilai Kedisiplinan Melalui Pembiasaan Salat Zuhur Berjamaah Siswa Kelas VII SMP N 2 Kec. Suruh Kab. Semarang Tahun Pelajaran 2017/2018", Disertasi Doktoral, (Semarang: IAIN Salatiga, 2018).

Jenuri, Rohendi, E., Rohayati, R. Pendidikan Agama Islam Mengokohkan Karakter Calon Guru Profesional, (Bandung: Rizqi Press, 2017).

Kemendiknas. Pengembangan Pendidikan Budaya dan Karakter Bangsa: Pedoman Sekolah. (Jakarta: Kemendiknas. 2010). Koesoema, Doni. Pendidikan Karakter Strategi Mendidik Anak di Zaman Global. (Jakarta: Grasindo, 2011).

Majid, A., \& Andayani, D. Pendidikan Karkater Perspektif Islam, (Bandung: PT Remaja Rosdakarya, 2013). 
Maulana, F. "Penanaman Kedisiplinan pada Siswa Melalui Ibadah Praktis di SD Birrul Walidain Muhammadiyah Sragen", Disertasi Doktoral, (Yogyakarta: Universitas Muhammadiyah Surakarta, 2002).

Mas'at, B. A. S. “Pembentukan Karakter Disiplin Santri Melalui Amaliyah Yaumiyyah di Pondok Pesantren al Hikmah 2 Benda Sirampog Brebes". Disertasi Doktoral. (Malang: Universitas Islam Negeri Maulana Malik Ibrahim Malang, 2019).

Maysaroh. "Pembinaan Karakter Siswa Sekolah Dasar Melalui Program Pembiasaan Malam Bina Iman dan Takwa: Studi Kasus di Kelas IV SDIT Al-Hanif Tahun Ajaran 2018/201". Skripsi. (Serang: Universitas Pendidikan Indonesia Kampus Serang, 2019).

Novitasari, A. Pemberian Reward and Punishment dalam Membentuk Karakter Disiplin Anak pada Sekolah Madrasah Ibtidaiyah. Halaqa: Islamic Edication Journal 3, No.1 (2019): 27-33.

https://doi.org/10.21070/halaqa.v3i1.2113

Nugroho, K. P. “Pembentukan Karakter Disiplin Siswa Melalui Pembiasaan Salat Dhuha SLB N Purbalingga Tahun Pelajaran 2016/2017". Disertasi Doktoral. (IAIN Purwokerto, Purwokerto,nu 2017). 
Nuryati, H. “Pembiasaan Salat Berjama'ah dalam Membentuk Karakter Disiplin Siswa SMA Negeri Piyungan Kabupaten Bantul". Tesis. (Universitas Islam Indonesia, Bantul, 2018).

Patilima, H. Metode penelitian kualitatif, (Bandung: Alfabeta, 2005). Sadulloh, Pedagogik (Ilmu Mendidik), (Bandung: Alfabeta, 2017).

Senja. Upaya Pembinaan Karakter Disiplin pada Anak Usia Sekolah Dasar Melalui Program Pembiasaan Salat Subuh Berjamaah. Skripsi. (Serang: Universitas Pendidikan Indonesia, 2015).

Sugiyono. Metode Penelitian Kualitatif Untuk Penelitian Yang Bersifat: Eksploratif, Enterpretif, Interaktif, dan Konstruktif, (Bandung: Alfabeta, 2017).

Wahyuni, U., Batubara, S., \& Hasanah, N. Implementasi Pembiasaan Shalat Berjama'ah dalam Pembentukan Karakter Disiplin Mahasantri Putri Ma'had Al-Jami'ah Universitas Islam Negeri Sulthan Thaha Saifuddin Jambi. Disertasi Doktoral, (Jambi: UIN Sulthan Thaha Saifuddin, 2019).

Widjaja, M. Y. A. (2020). Konsep Spiritual Leadership Menghidupkan Sunnah Harian Nabi Muhammad dalam Pembentukan Karakter SDI di Era Millenial. Saujana: Jurnal Perbankan Syariah dan Ekonomi Syariah, 2(1), 69-84. 